\title{
Оцінка прогностичних критеріів перебігу псоріазу для подальшої корекціі лікування пацієнтів у післяопераційному періоді
}

\author{
Р. Л. Степаненко, Т. С. Коновалова, В. І. Степаненко, В. М. Іванцок
}

Національний медичний університет імені О. О. Богомольця, м. Київ

\section{Estimation of prognostic criteria in the psoriasis course for further correction of treatment in patients postoperatively}

\author{
R. L. Stepanenko, T. S. Konovalova, V. I. Stepanenko, V. M. Ivantsok \\ Bogomolets National Medical University, Kyiv
}

\section{Реферат}

Мета. Дослідити імуногістохімічні зміни в шкірі хворих із псоріазом для прогнозування можливого загострення шкірного псоріатичного процесу після виконання оперативного втручання.

Матеріали і методи. Проведено імуногістохімічне дослідження біопсійного матеріалу, взятого з ділянок шкірної псоріатичної висипки та інтактної шкіри у хворих із псоріазом до виконання оперативного втручання. Крім того, для порівняння результатів імуногістохімічних досліджень вивчено біопсійний матеріал шкіри передньої черевної стінки, взятий у 5 практично здорових осіб відповідного віку після герніопластики. Для оцінки характеру та поширеності місцевих клітинних імунних і запальних реакцій у шкірі хворих із псоріазом застосовували імуногістохімічні методики з визначенням експресії маркерів імунного запалення.

Результати. Представлені результати дослідження змін імуногістохімічної експресії прозапальних біологічних маркерів у шкірі хворих із псоріазом до виконання оперативного втручання з подальшим аналізом впливу такого стресового фактора, як оперативне втручання, на перебіг шкірного псоріатичного процесу.

Висновки. Доведено, що одним із механізмів загострення запальних реакцій у хворих із псоріазом є активація імунокомпетентних клітин, зокрема через Toll-рецептори, що дає можливість скоригувати тактику лікування пацієнтів у післяопераційному періоді.

Ключові слова: псоріаз; імуногістохімічні зміни в шкірі; Toll-подібні рецептори; оперативне втручання.

\section{Abstract}

Objective. To investigate immunohistochemical changes in the skin of patients, suffering psoriasis, for prognostication of possible postoperative exacerbation of cutaneous psoriatic process.

Materials and methods. There was conducted preoperative immunohistochemical investigation of the biopsy material, obtained from sites of cutaneous psoriatic rashes and intact skin in patients, suffering psoriasis. Besides this, for comparison of the immunohistochemical results the cutaneous biopsy material of anterior abdominal wall was, obtained in 5 practically healthy persons of a certain age after performance of hernioplasty. For estimation of character and spreading of local cellular reactions in the skin of the patients, suffering psoriasis, immunohistochemical procedures were applied for determination of expression of the immune inflammation markers.

Results. Results of preoperative investigation of changes in immunohistochemical expression of proinflammatory biological markers in the skin of psoriatic patients, with further analysis of impact of such stressful factor, as operative intervention, have witnessed its influence on the cutaneous psoriasis course.

Conclusion. There was proved, that one of mechanisms of the inflammatory reactions exacerbation in patients, suffering psoriasis, constitutes activation of immunocompetent cells, including those, which are acting via the Toll-receptors, what makes possible to improve the tactics of treatment in patients during postoperative period.

Keywords: psoriasis; immunohistochemical changes in the skin; Toll-like receptors; operative intervention.

Псоріаз вважають системним захворюванням організму, за наявності якого виникають функціональні й органічні зміни в травній, гепатобіліарній, серцево-судинній та ряді інших систем, що унеможливлює лікування хірургічної патології у пацієнтів із псоріазом згідно зі стандартними схемами, особливо в післяопераційному періоді. Незважаючи на численні дослідження, етіологія і патогенез псоріазу залишаються до кінця нез'ясованими, виділено лише певні провідні чинники і механізми розвитку псоріазу, зокрема, імунологічні та генетичні, а також вплив стресового фактора [1].
Загальновизнано, що запалення в шкірі хворих із псоріазом починається з активації клітин шкіри. Імунна система залучається в розвиток запального процесу набагато пізніше після проникнення через шкіру невідомого патогена - тоді, коли активовані клітини шкіри не можуть самостійно знищити патоген і забезпечити переривання «доімунного» запалення. За цей час патогени не «мандрують» вільно по організму, оскільки їх розпізнають як «чужаків» структури кератиноцитів. Усередині 90-х років ХХ століття ряд авторів назвали цих «чужаків» «патоген-асоційованими молекулярними образами» (pathogen 
associated molecular patterns - PAMP), яких немає у багатоклітинних організмах $[2,3]$. РАМР розпізнаються так званими Toll-подібними рецепторами (Toll-liked receptors TLR) [4] - трансмембранними білковими структурами, до складу яких входять мембранні і цитоплазматичні ділянки.

В організмі людини більшість TLR експресуються макрофагами, моноцитами, нейтрофілами, також їх виявлено на епітеліоцитах кишечника, ендотелії судин і кератиноцитах шкіри [5].

Ряд авторів вважає, що TLR активовані кератиноцити здатні моделювати адаптивну імунну відповідь [6]. Окремі дослідники встановили, що TLR-стимульовані кератиноцити супернатанта викликають дозрівання дендритних клітин [7]. Роль та функцію TLR у шкірі людини вивчають порівняно недавно. Активацію TLR виявлено при деяких захворюваннях шкіри інфекційної етіології.

Мета дослідження: вивчення експресії TLR клітинами шкіри для прогнозування загострення шкірного псоріатичного процесу та коригування тактики лікування хворих у післяопераційному періоді.

\section{Матеріали і методи дослідження}

У хворих із псоріазом вульгарним до виконання хірургічного втручання з приводу різноманітної хірургічної патології проводили двократне дослідження біопсійного матеріалу, взятого, зокрема, з ділянок шкіри, ураженої псоріатичною висипкою, та з ділянок інтактної шкіри. Крім того, для порівняння результатів імуногістохімічного дослідження вивчено біопсійний матеріал шкіри передньої черевної стінки, взятий у 5 практично здорових осіб відповідного віку після герніопластики. Фрагменти біопсійного матеріалу шкіри фіксували в 10\% розчині нейтрального формаліну зневоднювали у спиртах та заливали в парафінові блоки, з яких виготовляли гістологічні зрізи товщиною 4 - 6 мкм.

Під час постановки імуногістохімічних реакцій для демаскування антигенів проводили теплову обробку зрізів та блокували неспецифічне зв'язування білків протеїновим блоком DAKO й ендогенну пероксидазну активність пероксидазним блоком DAKO, після цього наносили первинні антитіла, які визначали за допомогою системи детекції DAKO EnVizion+. Для візуалізації гістологічних структур імуногістохімічні препарати дофарбовували гематоксиліном Маєра, покривали канадським бальзамом та покривними скельцями. Після цього за кількістю клітин, які мали чітку позитивну реакцію, з урахуванням інтенсивності забарвлення обліковували позитивні реакції. Клітини з позитивною експресією вивчали у 4 - 6 випадково обраних полях зору мікроскопа. Результати імуногістохімічних реакцій оцінювали шляхом підрахунку клітин з позитивним забарвленням у 10 випадково обраних полях зору мікроскопа за збільшення у 400 разів. Оцінювали ступінь інтенсивності забарвлення: 0 - немає забарвлення, 1 (+) - слабке забарвлення світло-коричневим кольором, $2(++)$ - помірне забарвлення коричневим кольором, 3 (+++) - виражене забарвлення темно-корич- невим кольором. Результати імуногістохімічної реакції оцінювали напівкількісним методом у балах (від 0 до 6) за загальноприйнятою методикою з урахуванням забарвлених клітин: 0 балів - немає забарвлених клітин, 1 бал - до 10\%, 2 бали - до 20\%, 3 бали - до 30 \%, 4 бали - до 40\%, 5 балів - до 50 \%, 6 балів - більше 50\% забарвлених клітин.

Для вивчення характеру і поширеності місцевих клітинних імунних і запальних реакцій в шкірі застосовували імуногістохімічні методики з визначенням прозапальних маркерів імунного запалення.

Імуногістохімічні препарати вивчали з використанням мікроскопа Olympus BX 51, цифрової камери Olympus C 5050 Z та програмного забезпечення Olympus DP-Soft. Дослідження проведено в Інституті патології Карл-ТімКлінікум (академічна школа Шаріте, м. Котбус, Німеччина).

\section{Результати}

У біоптатах $з$ ділянок інтактної шкіри хворих спостерігали явища гіперкератозу, вогнищевого дискератозу та набряк епідермісу, в його базальному шарі - підвищену проліферативну активність, формування мікробляшок, в підлягаючій дермі - легку запальну інфільтрацію. Спостерігали також вростання судин у сосочок дерми 3 відшаруванням епідермісу і утворенням мікроерозій.

Під час імуногістохімічного дослідження біоптатів 3 ділянок інтактної шкіри хворих виявляли структурні зміни, які вказували на присутність у сосочковому шарі дерми імунокомпетентних клітин. В основі сосочків містились легкі запальні інфільтрати переважно з CD4-позитивних лімфоцитів, найбільшу активність яких реєстрували в запальних периваскулярних інфільтратах дерми. Також визначено аналогічну локалізацію CD8-позитивних клітин та виявлено поодинокі CD20 - та CD56-позитивні клітини. Периваскулярно в основі сосочків і в самих сосочках спостерігали значну кількість CD68-позитивних клітин.

Дослідженням експресії TLR2 в ділянках інтактної шкіри хворих із псоріазом визначено позитивну реакцію 3 ядерним забарвленням у макрофагах, дендритних клітинах епідермісу та ендотелії кровоносних судин дерми; експресії TLR4 - інтенсивне і поширене ядерне і цитоплазматичне забарвлення клітин усіх шарів епідермісу, в тому числі зроговілого шару;

експресії TLR9 - значну кількість TLR9-позитивних епітеліоцитів у всіх шарах епідермісу, в тому числі в поверхневих, дифузну реакцію в клітинах, що характеризувалось як ядерним, так і цитоплазматичним забарвленням, експресію TLR9 виявляли також у поодиноких запальних клітинах і дрібних їх скупченнях у сосочковому шарі дерми.

За результатами проведених імуногістохімічних досліджень зроблено висновок про те, що для ділянок інтактної шкіри хворих з прогресуючою стадією перебігу псоріазу характерна гіперпродукція TLR, що є підгрунтям для розвитку реакції імунокомпетентних клітин і формування нових морфологічних елементів псоріатичної висипки.

Морфологічні дослідження біоптатів шкіри хворих, взятих з ділянок, уражених псоріатичною висипкою, по- 
казали наявність комплексу запальних, гіперпластичних і дисрегенеративних реакцій. Зокрема, спостерігали потовщення епідермісу, надмірне утворення кератину, збільшення кількості сосочків, які глибоко проникали в епітеліальний шар. В епідермісі відбувалась папіломатозна гіперплазія безпосередньо навколо сосочків, проліферація епітеліоцитів. Навколо верхівки сосочків в епідермісі утворювався «чепчик» із смужки набряклих епітеліоцитів і зони інтерцелюлярного набряку. Нижче рогового шару виявляли тангенціальні дрібні крововиливи, обумовлені пошкодженням верхівок сосочків. У роговому шарі епідермісу була наявна кров, що могла слугувати живильним середовищем для мікроорганізмів та вірогідно мала значення для утворення мікроабсцесів Мунро. Перифокально спостерігали міжклітинний набряк з акантозом. В епітеліоцитах реєстрували деструктивно-дистрофічні зміни, а також наявність у ділянках деструкції лімфоїдних клітин.

Характерною морфологічною ознакою активності псоріатичного процесу є встановлена наявність запальних інфільтратів у сосочковому шарі дерми та безпосередньо в сосочках. Варто зазначити, що ці периваскулярні інфільтрати в основі сосочків включали переважно лімфоїдні клітини і макрофаги.

В основі сосочків та безпосередньо в сосочках спостерігали проліферацію епітеліоцитів і фібробластів, присутність клітин хронічного запалення з формуванням судинного тяжа, в сосочковому шарі - утворення «муфт» навколо судин. Також виявляли новоутворені кровоносні судини. Навколо «муфт» формувалась капсула з колагенових волокон. Морфологічно сосочок представляв собою футляр з колагенових волокон і кількох кровоносних судин у центрі сосочка. Периваскулярно виявляли декілька лімфатичних судин, по яких від верхівки сосочка і набряклого епітеліального шару відтікали міжклітинна рідина та лімфа. В просвіті цих лімфатичних судин виявляли значну кількість великих макрофагів з гранулярною ци-

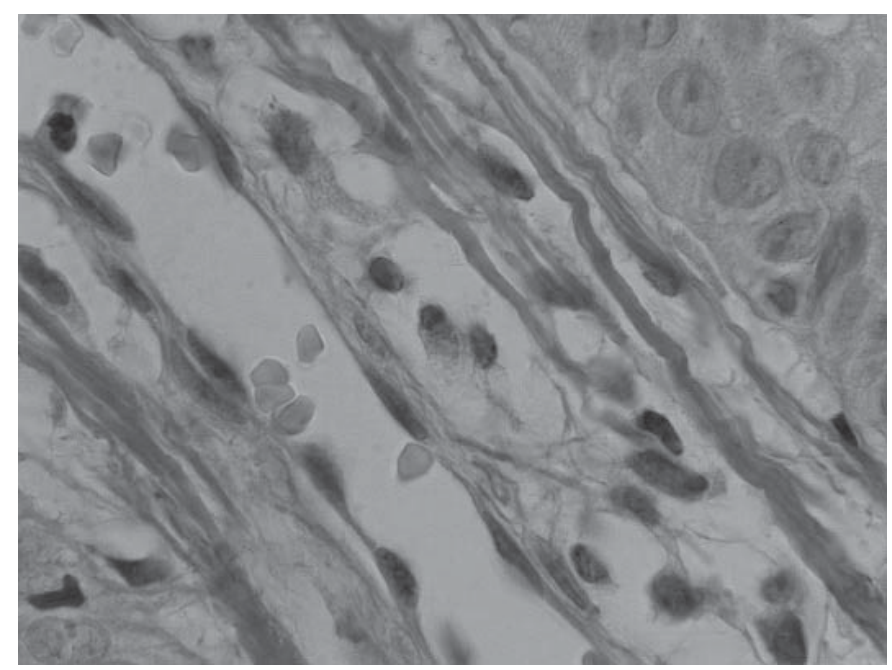

Puc. 1.

Мікрофото.

Макрофаги в ліпфатичних судинах сосочка. Забарвлення за Ван-Гізон. Зб. ×1000. топлазмою (рис. 1). Стінки кровоносних судин мали вигляд інтактних, за винятком ознак незначного набряку, що свідчило про відсутність у них імунних реакцій, а також вказувало на відсутність компонентів імунних реакцій у плазмі крові.

Потрібно зазначити, що судинний пучок, який відходить від судинного сплетення в основі сосочка до самого сосочка, складається з артеріальних, венозних і лімфатичних судин. Саме по лімфатичних судинах від епітеліального шару відтікають потенційні антигени і медіатори, на які можлива реакція лімфоїдних клітин і макрофагів. Відповідну реакцію у вигляді інфільтратів спостерігали в ділянках, безпосередньо прилеглих до просвітів лімфатичних судин в основі сосочків. Встановлено також наявність запальних клітин (лімфоїдні елементи, макрофаги) у просвітах лімфатичних судин та в інтерстиції поряд. У лімфатичній системі спостерігали лімфостаз і розширення сітки лімфатичних судин як у сосочках, так і в колекторних судинах у сосочковому шарі дерми.

Проведені нами дослідження дають підстави для припущення, що через значне потоншення, набряк та розпушування епітеліальний шар легко пошкоджується і в тканину сосочка проникають зовнішні патогенні інфекційні чинники. Внаслідок цього виникають мікроабсцеси Мунро. У сітчастому шарі дерми, зокрема, тільки у верхніх відділах дерми, які межують з сосочковим шаром, виникає вогнищева запальна інфільтрація.

У разі прогресування шкірного псоріатичного процесу антигени проникають у дерму з епітеліального шару, що підтверджується виявленням найбільш виражених хронічних запальних інфільтратів в основі сосочків, куди відтікає лімфа з епітеліального шару і де розміщуються колекторні лімфатичні судини. Таким чином, імунопатологічні процеси відбуваються не в стінках кровоносних судин, а в інтерстиції, зокрема, в лімфатичних судинах і навколо них. Це дає підставу стверджувати, що в морфо-

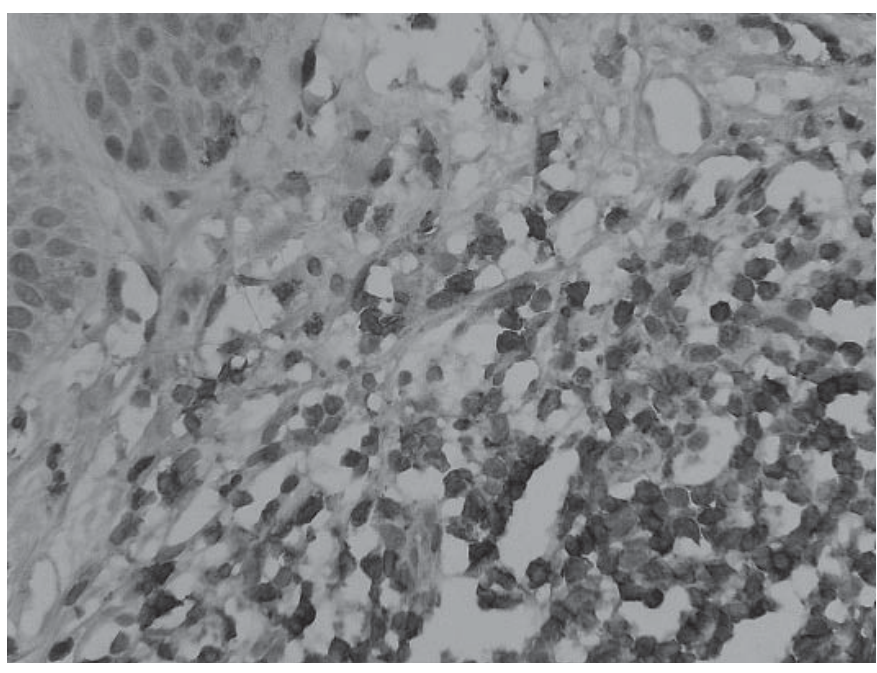

Puc. 2.

Мікрофото.

Псоріатична блямка. Значна кількість CD4-позитивних клітину запальному інфільтраті в сосочковому шарі дерми. 36. $\times 400$. 


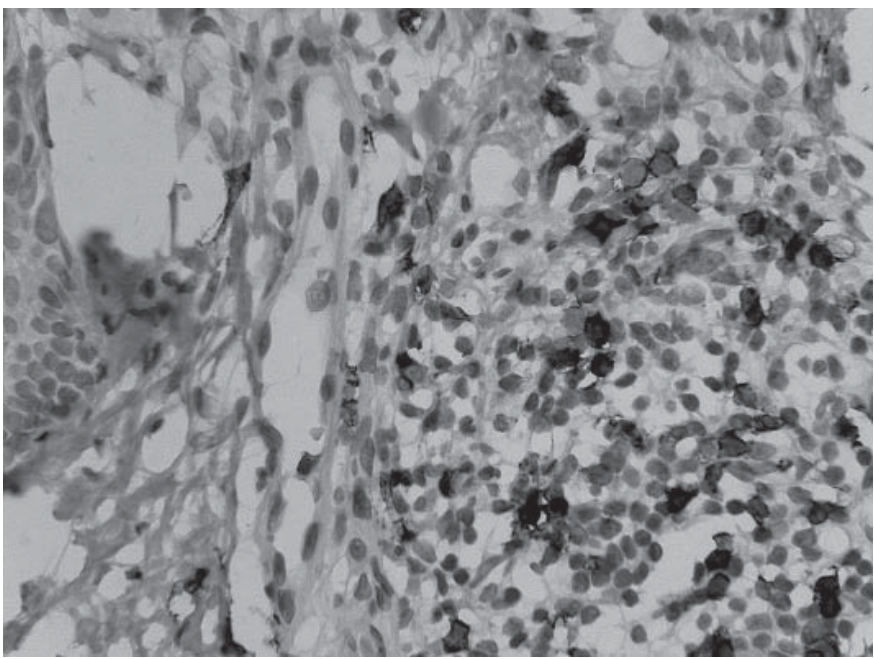

Puc.3.

Мiкрофото.

Псоріатична бляшка. Значна кількість CD8-позитивних клітин у запальному інфільтраті в сосочковому шарі дерми. 36. $\times 400$.

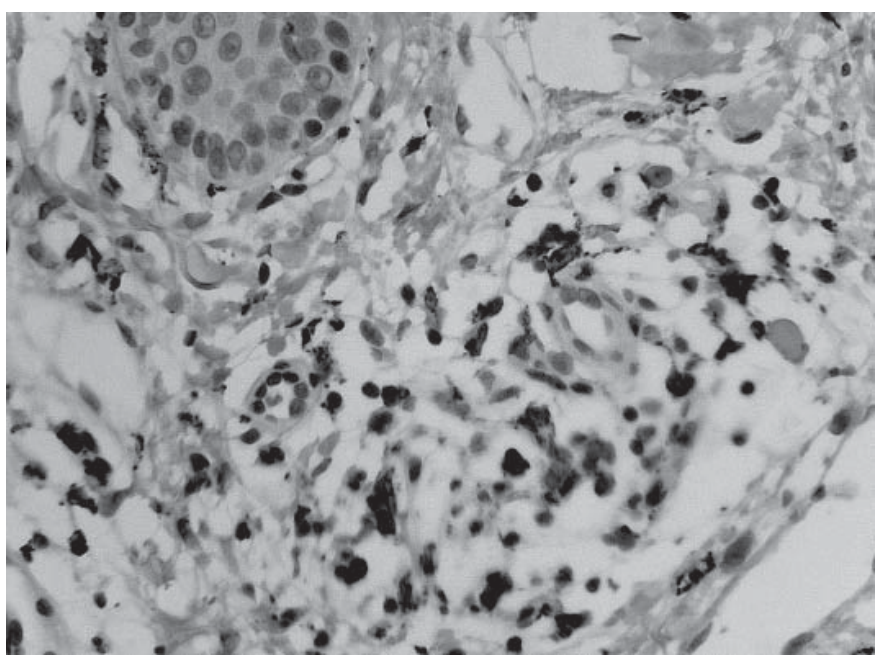

Puc. 5 .

Мiкрофото.

Псоріатична блячка. СD68-позитивніклітини

в периваскулярному інфільтраті сосочкового шару дерми. 36. $\times 400$.

генезі шкірної псоріатичної висипки суттєву роль відіграють процеси проліферації сполучнотканинних елементів, перш за все судинних, а також самого епідермісу.

Проведені нами імуногістохімічні дослідження ділянок шкіри, ураженої псоріатичною висипкою, у хворих з прогресуючою стадією перебігу псоріазу дали змогу виявити комплекс структурних змін, які вказують на суттєве значення імунопатологічних реакцій у патогенезі цього дерматозу. Зокрема, у сосочковому шарі дерми та на межі сосочкового і сітчастого шарів дерми виявляли запальні інфільтрати, в яких визначали до 50\% CD4-позитивних клітин (рис. 2), що вказувало на присутність індукованих Т-хелперів.

У периваскулярних інфільтратах в основі сосочків дерми частка CD4-позитивних клітин становила до 40\% від

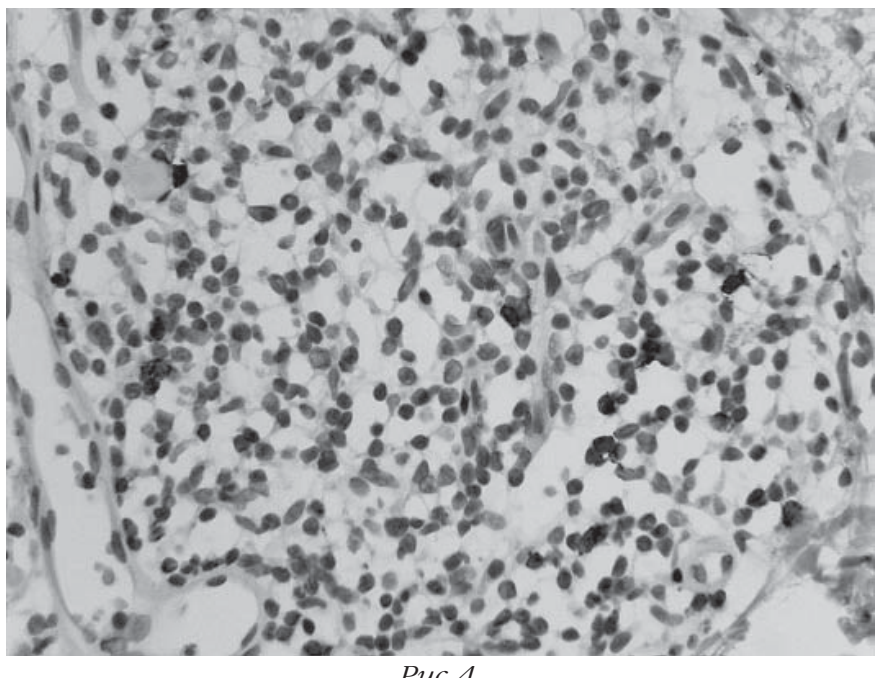

Puc. 4.

Miкpoфбото.

Псоріатична бляшка. СD56-позитивні клітини в запальному інфільтраті сосочкового шару дерми. 36. $\times 400$.

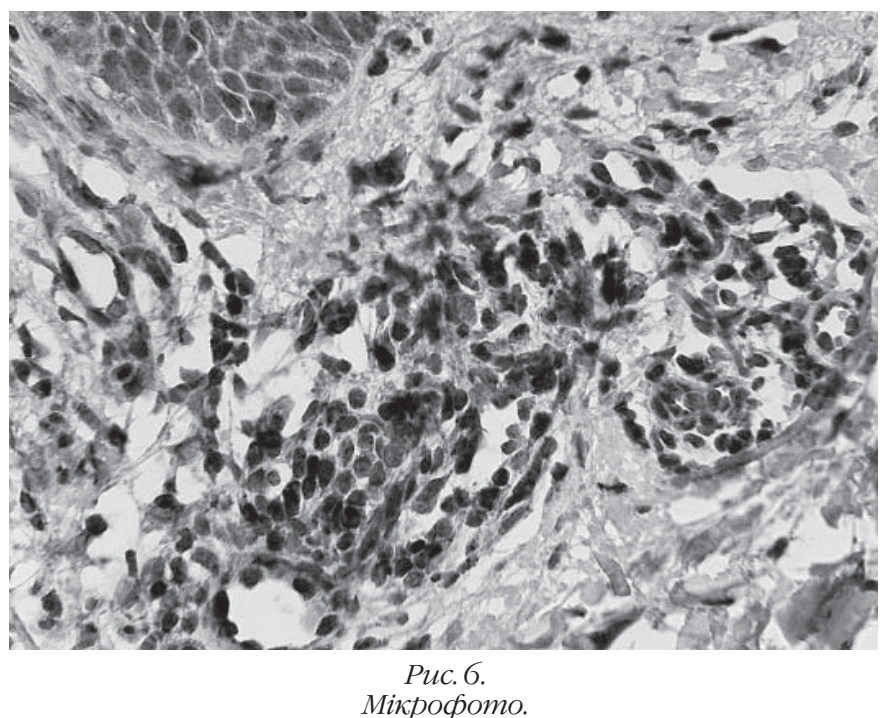

ділянка шкірної псоріатичної висипки хворого із псоріазом.

Мембранна експресія в макрофагах сосочків дерми і макрофагах, що мігрують в епітеліальний пласт. Реакція на виявлення експресії TLR4.36. ×400.

усієї кількості запальних клітин, частка CD8-позитивних клітин була трохи меншою - до 30\% (рис. 3) Встановлено також активну міграцію CD8-позитивних клітин із сосочків в епітеліальний шар. Збільшення кількості CD8-позитивних клітин у ділянках деструкції епідермісу супроводжувалось лейкоцитарною інфільтрацією, що вказувало на цитотоксичний ефект CD8-позитивних клітин по відношенню до епітеліоцитів. Тісні контакти CD8-позитивних клітин та епітеліоцитів виявляли переважно в ростковій зоні у верхівках сосочків. Ядра епітеліоцитів, з якими контактували CD8-позитивні клітини, були збільшені, містили одне або декілька ядерець. Такі зміни ядер епітеліоцитів свідчать про присутність у них антигенних компонентів.

У запальних інфільтратах в основі сосочків та їх верхівках спостерігали нечисленні CD20-позитивні клітини. 
Міграції їх в епітеліальний шар не виявлено. У запальних інфільтратах дерми спостерігали також незначну кількість CD56-позитивних клітин (рис. 4), яка становила 1 - 2\% від загальної кількості запальних клітин. У запальних інфільтратах в дермі, зокрема на межі сосочкового шару та в сосочках, особливо в їх верхівках, виявляли CD68-позитивні клітини в кількості, яка становила до 10\% від загальної кількості клітин інфільтрату (рuс. 5). Простежували також периваскулярне розташування CD68-позитивних клітин та ознаки їх міграції із сосочків у дерму та у зворотному напрямі по ходу лімфатичних і кровоносних капілярів. CD68позитивні клітини контактували з лімфоїдними елементами. Виявлена також міграція CD68-позитивних клітин в епітеліальний шар до поверхневих ділянок епідермісу.

Імуногістохімічною реакцією на виявлення експресії TLR4 в ділянках шкірної псоріатичної висипки до оперативного втручання визначено фонове дифузне цитоплазматичне і ядерне забарвлення клітин епідермісу, ендотелію судин і поодиноких макрофагальних клітин (рис. б). Кількість позитивно забарвлених клітин епідермісу становила до 80\%. Найбільш інтенсивне забарвлення спостерігали в макрофагах, розташованих у сосочках і периваскулярно в дермі.

Iмуногістохімічне дослідження експресії TLR2 виявило менш інтенсивне дифузне фонове забарвлення епідермісу, ендотелію судин і частини клітин у запальних інфільтратах дерми. Встановлена виражена мембранна експресія TLR4 численими макрофагами сосочків дерми. Виявлено феномен позитивного ядерного мембранного забарвлення епітеліальних клітин, що межують із зроговілими масами на поверхні шкіри. В сосочковому шарі дерми спостерігали характерну мембранну експресію TLR4 як в окремих макрофагах, розташованих периваскулярно, так і в периваскулярних запальних інфільтратах. Топографічно простежувалась локалізація макрофагів у лімфатичних судинах, по яких лімфа відтікає в напрямку від верхівки сосочків до їх основи, де є скупчення судин. Створюються умови, коли ліганди мікроорганізмів можуть вільно проникати до сосочкового шару і реагувати з макрофагами, які активно мігрують до верхівки сосочків та навіть проникають в епітеліальний пласт, активуючись, збільшуючись, активно експресуючи TLR2 та TLR4. Очевидно, що макрофаги після активації мігрують до основи сосочків, де залучаються у запальні інфільтрати, розташовані периваскулярно. В цих ділянках відбувається основна взаємодія макрофагів та лімфоїдних клітин.

Імуногістохімічним дослідженням встановлено значну експресію TLR9 у клітинах запального інфільтрату в сосочковому шарі дерми і в епідермісі. Макрофаги, які мігрували в судинах сосочків дерми, мали виражену позитивну експресію маркера. TLR9-позитивні макрофаги і моноцити виявляли в судинах і периваскулярному просторі сосочкового шару дерми. TLR9-позитивні клітини спостерігали також в епідермісі в ділянках набряку. Епітеліоцити проявляли слабку і помірну ядерну та цитоплазматичну реакцію. Встановлено, що частина TLR9-позитивних клі- тин в епідермісі мігрувала із сосочкового шару дерми. До таких клітин належали макрофаги і активовані лімфоїдні елементи, а також нейтрофільні гранулоцити. Останні позитивно забарвлювались особливо в ділянках формування під роговим шаром мікроабсцесів Мунро. Враховуючи, що на стадії прогресування в ділянках шкірного псоріатичного ураження виникають набряк, акантоз і десквамація епітеліоцитів, це уможливлює проникнення бактеріальної мікрофлори. Позитивну експресію TLR9 встановлено в колоніях мікроорганізмів, внутрішньоклітинно в гранулоцитах і макрофагах за умови їх фагоцитозу. За наявності мікроабсцесів Мунро у прилеглих сосочках дерми було виявлено найбільшу кількість різко TLR9-позитивних гранулоцитів та макрофагів.

\section{Обговорення}

Проаналізувавши результати проведених досліджень, ми припустили, що частина TLR9-позитивних клітин переміщується з епітеліального пласта в лімфатичні дренажі, цитоплазму фагоцитуючих клітин, які зворотно мігрують у дерму і активують запальні реакції. У разі прогресування псоріатичного процесу відбуваються суттева міграція макрофагів у базальні відділи епідермісу і контакти цих клітин з TLR9-позитивними епітеліоцитами. Крім того, в периваскулярних просторах сосочкового шару дерми виявлено певну кількість TLR9-позитивних гранулоцитів, що розташовувалися позаклітинно, зокрема у верхівках сосочків. Таким чином, гіперпродукція цього біологічного маркера в епідермісі супроводжується надходженням його в дерму через лімфатичні колектори або у складі фагоцитів. Встановлено важливі патогенетичні ланки загострення шкірного псоріатичного процесу, що дає можливість відкоригувати лікування пацієнтів у післяопераційному періоді.

\section{Висновки}

1. У псоріатичних запальних інфільтратах переважали CD4-, CD8- та CD68-позитивні клітини.

2. Імунокомпетентні клітини концентрувалися в сосочках дерми на межі з епідермісом і в самому епідерміci, а також у периваскулярних просторах сосочкового шару дерми. Очевидно, що це пов'язано з місцями концентрації антигенів.

3. Виявлена міграція перш за все CD4-, CD8- та CD68позитивних клітин в епітеліальний шар аж до поверхневих рогових мас. Також значна кількість CD68-позитивних клітин мігрувала по сосочках у зворотному напрямку - від епідермісу в дерму (по ходу лімфатичних капілярів).

4. Встановлено наявність гіперпродукції і гіперсекреції епітеліоцитами шкіри прозапальних біологічних маркерів, зокрема TLR2-, TLR4- та TLR9-позитивних клітин, які виявляли як у шкірі, ураженій псоріатичною висипкою, так і в інтактній шкірі, але кількість таких клітин у шкірі з псоріатичними бляшками була більшою, ніж в інтактній шкірі.

5. TLR2-, TLR4- та TLR9-позитивні макрофаги після ix активації в сосочках дерми мігрують до основи сосоч- 
ків, де включаються у склад запальних інфільтратів, розташованих периваскулярно. В цих ділянках відбувається основна взаємодія макрофагів та лімфоїдних клітин.

\section{Підтвердження}

Фінансування. Це дослідження є фрагментом планової НДР. Фінансування за рахунок держбюджету.

Внесок авторів. Внесок кожного автора в цю роботу однаковий. Всі автори прочитали і схвалили остаточний варіант рукопису.

Конфлікт інтересів. Автори, які взяли участь у цьому дослідженні, декларують відсутність конфлікту інтересів щодо цього рукопису.

Згода на публікацію. Всі автори дали згоду на публікацію цього рукопису.

\section{References}

1. Lima EA, Lima MA. Reviewing concepts in the immunopathogenesis of psoriasis. An Bras Dermatol 2011; 86(6):1151-8. https://doi.org/10.1590/ S0365-05962011000600014. [In Espanol].

2. Takeda K, Akira S. Toll-receptors in innate immunity. Int Immunol. 2005 Jan; 17(1):1-14. https://doi.org/10.1093/intimm/dxh186.

3. Janeway CA Jr, Medzhitov R. Innate immune recognition. Annu Rev Immunol. 2002;20:197-201. https://doi.org/10.1146/annurev.immunol.20.083001.084359.

4. Kopp EB, Medzhitov R. The Toll-receptor family and control of innate immunity. Curr Opit Immunol. 1999 Feb; 11(1):13-28. PMID: 10047546.

5. Zhang D, Zhang G, Hayden MS, Greenblatt MB, Bussey C, Flavell RA, et al. A toll-like receptor that prevents infection by uropathogenic bacteria. Science. 2004 Mar 5;303(5663):1522-6. https://doi.org/10.1126/ science.1094351.

6. Mclnturff R, Modlin JK, Kim J. The role of toll-like receptors in the pathogenesis and treatment of dermatological disease. J Invest Derm. 2005;125(1):1-8. https://doi.org/10.1111/j.0022-202X.2004.23459.x.

7. Akira S, Takeda K, Kaisho T. Toll-like receptors: critical proteins linking innate and acquired immunity. Nat Immunol. 2001 Aug; 2(8): 67580. https://doi.org/10.1038/90609. 